\title{
Hypoxia-activated pro-drugs of the KDAC inhibitor Vorinostat (SAHA)
}

Ewen D. D. Calder, ${ }^{1}$ Anna Skwarska, ${ }^{2}$ Deborah Sneddon, ${ }^{1}$ Lisa K. Folkes, ${ }^{2}$ Ishna N. Mistry, ${ }^{2}$ Stuart J. Conway, ${ }^{1 *}$ and Ester M. Hammond ${ }^{2 *}$

${ }^{1}$ Department of Chemistry, Chemistry Research Laboratory, University of Oxford, Mansfield Road, Oxford, OX1 3TA, UK.

${ }^{2}$ Oxford Institute for Radiation Oncology, Department of Oncology, University of Oxford, Old Road Campus Research Building, Oxford, OX3 7DQ, UK.

This paper is dedicated to Professor Steve Davies.

${ }^{*}$ corresponding authors

Stuart Conway

Stuart.conway@chem.ox.ac.uk

ORCID - 0000-0002-5148-117X

Ester Hammond

Ester.hammond@oncology.ox.ac.uk

ORCID - 0000-0002-2335-3146 


\begin{abstract}
Hypoxia (lower than normal oxygen) is a characteristic of most solid tumours that results in poor cancer patient prognosis. The difference in cellular environment between normoxia ( $21 \%$ oxygen) or physoxia (4-7.5\% oxygen) and hypoxia (<2.0\% oxygen) causes increased resistance to radio- and chemotherapy, but also provides the opportunity to selectively release hypoxia-activated pro-drugs. This approach potentially allows targeting of chemotherapies, including lysine deacetylase (KDAC) inhibitors, to the hypoxic fraction of cells. Here, we report initial work on the development of KDAC inhibitors that are selectively released in hypoxic conditions. We have shown that the addition of a 4-nitrobenzyl (NB) or 1-methyl-2-nitroimidazole (NI) bioreductive group onto the hydroxamic acid moiety of SAHA, giving NB-SAHA and NI-SAHA, abolishes KDAC inhibition activity. Both NB-SAHA and $\mathrm{NI}$-SAHA undergo enzyme-mediated bioreduction, in a hypoxia-dependent manner, to release SAHA selectively in $<0.1 \%$ oxygen. This work provides an important foundation for further investigations into the targeted release of KDAC inhibitors in hypoxic tumours.
\end{abstract}




\section{INTRODUCTION}

Acetylation of the $\varepsilon$-nitrogen atom of lysine residues was identified in $1964^{1}$ and has emerged as a functionally-important post-translational modification (PTM), with comparable complexity and significance to phosphorylation. ${ }^{2}$ Lysine acetylation is found on proteins throughout the cell, ${ }^{3}$ with studies in A549, Jurkat, and MV4;11, cells identifying 3600 occurrences of lysine acetylation in 1750 proteins. ${ }^{4}$ A particular focus on the role of lysine acetylation in histone proteins, which are involved in gene transcription, has led to lysine acetylation being considered a component of the epigenetic code. ${ }^{5}$ Lysine acetylation is a dynamic PTM, with histone/lysine acetyl transferase (H/KAT) enzymes identified that transfer an acetyl group from acetyl co-enzyme-A (AcCoA), and histone/lysine deacetylases (H/KDACs) that remove the acetyl group. ${ }^{6}$ Bromodomains have been identified as a class of protein modules that bind to acetylated lysine residues (KAc), making them readers of the epigenetic code..$^{7-9}$ Bromodomain-containing proteins function by promoting the formation of proteinprotein and protein-chromatin interactions, which often affect gene transcription. ${ }^{10,11}$

Lysine deacetylating and deacylating enzymes are subdivided into two mechanistically-distinct classes. The sirtuin enzymes (Sirt1-7) are NAD ${ }^{+}$dependent, while the KDACs (KDAC1-11) have a $\mathrm{Zn}^{2+}$-dependent mechanism. Five pan-KDAC inhibitors (belinostat, chidamide, vorinostat, panobinostat, and romidepsin) have been approved to date for clinical use, mainly for the treatment of T-cell lymphoma. ${ }^{6}$ All of these inhibitors possess a group that bind to the active site $\mathrm{Zn}^{2+}$ ion. For belinostat, vorinostat (SAHA, 1, Figure $1 \mathrm{~A}$ ), and panobinostat this group is a hydroxamic acid. While effective at binding to the $\mathrm{Zn}^{2+}$ ion in the KDAC enzymes, this moiety can potentially bind other offtarget metals or inhibit other off-target enzymes. This group is also very polar, hindering diffusion of hydroxamic acid-based compounds into cells and certain areas of the body, for example, the brain. In addition, this class of inhibitors prevents the function of all eleven $\mathrm{Zn}^{2+}$-dependent KDACs, meaning that the transcription of many genes is affected by these compounds. Perhaps as a consequence of these factors, KDAC inhibitors are linked to a number of serious side effects including fatigue, gastrointestinal issues (diarrhoea, nausea, vomiting), and hematologic complications (anaemia, neutropenia, thrombocytopenia,). ${ }^{12,13}$ In addition, SAHA (1) has a half-life of approximately 0.5 hours in human plasma, ${ }^{14}$ and $1.5-2.0$ hours when given orally to patients with advanced cancer. ${ }^{15}$ The main ways in which SAHA (1) is primarily metabolised are either through glucuronidation of the hydroxamic acid or hydrolysis of this group to give the corresponding carboxylic acid, which can undergo subsequent $\beta$-oxidation. All of these metabolic products are inactive in terms of KDAC inhibition. ${ }^{13,16}$ For these reasons, we are interested in developing prodrugs of KDAC inhibitors. These compounds will potentially circumvent these metabolic liabilities and improve compound permeation. However, our primary motivation is to develop pro-drugs that are activated in a given location or context, with the aim of minimising the side effects of SAHA (1). 


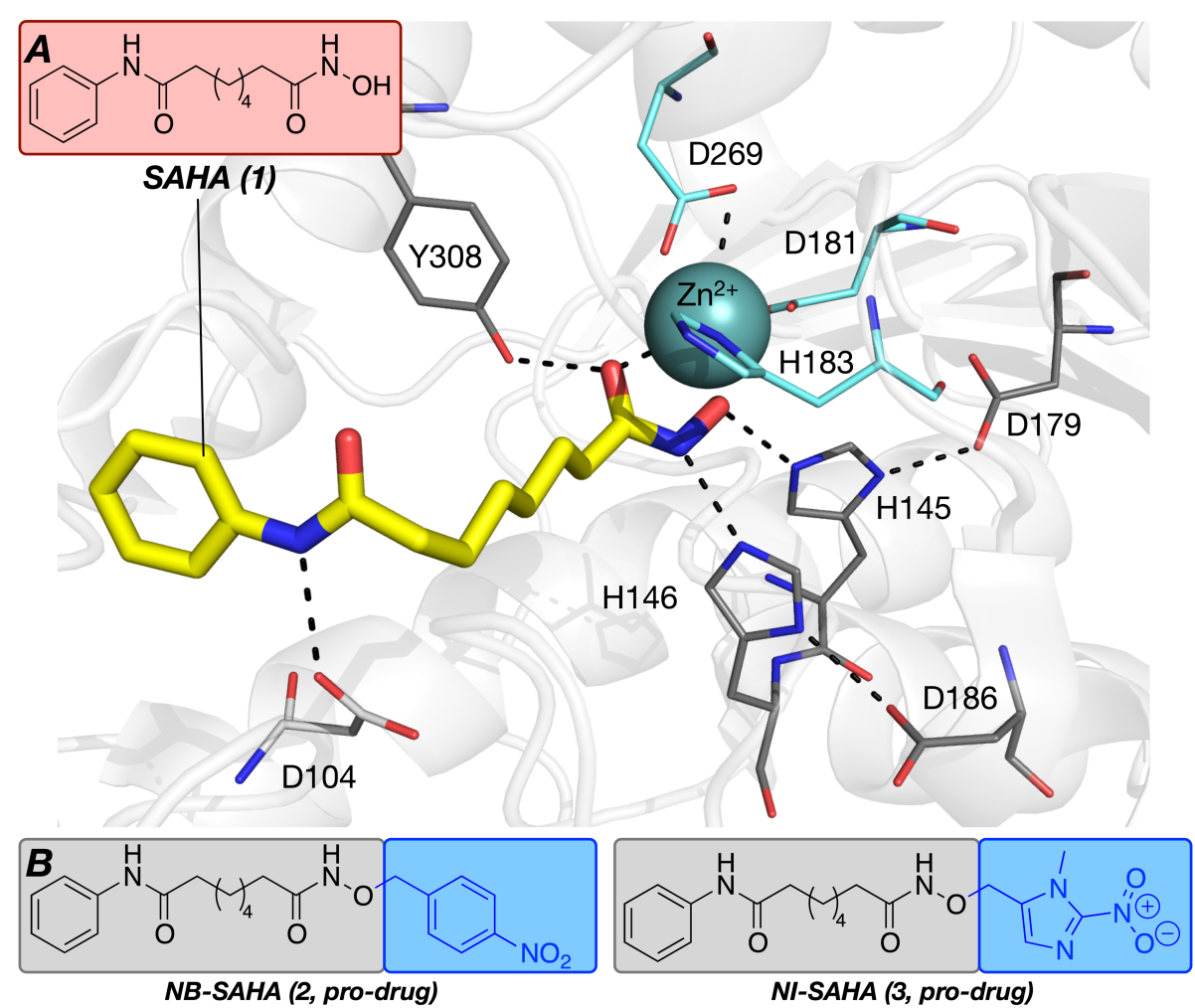

Figure 1A. The structure of SAHA (Vorinostat, 1) and an X-ray crystal structure of SAHA (1, carbon $=$ yellow) bound to the active site of KDAC2 $(\mathrm{PDB}$ code $4 \mathrm{LXZ}) \cdot{ }^{17-19} \mathrm{~B}$. The structures of 4-nitrobenzyl SAHA (NB-SAHA, 2) and 1-methyl-2-nitroimidazyl-SAHA (NI-SAHA, 3).

A small number of pro-drugs of SAHA have been reported previously. Schlimme et al. reported a carbamate pro-drug that is release in cells by hydrolysis, ${ }^{20}$ and Liu et al. recently reported a co-prodrug with paclitaxel. ${ }^{21}$ In both cases these compounds have no mechanism by which they are selectively released in a given location or context (e.g. cancer cells). In an attempt to target SAHA to cancerous cells, pro-drugs that are activated by thiols, ${ }^{13}$ reactive oxygen species, ${ }^{22}$ or hydrogen peroxide or peroxynitrite have been developed. ${ }^{23}$ Rubio-Ruiz have reported pro-drug of SAHA that can be activated using a $\mathrm{Pd}$-functionalised resin in glioblastoma or lung cancer cell lines. ${ }^{24}$ In all of these strategies the pro-moiety was added to the oxygen atom of the hydroxamic acid group so as to reduce compound polarity and minimise metabolism at this position. To the best of our knowledge, however, there are no reports of SAHA (1) pro-drugs that are activated by hypoxia (lower than normal oxygen).

Hypoxia is a characteristic of most solid tumours, which results from high metabolic demand and abnormal vasculature ${ }^{25}$ Hypoxic tumours are associated with aggressive tumour phenotypes and increased resistance to radio- and chemotherapy, which results in poor cancer patient prognosis. ${ }^{26}$ Consequently, while the hypoxic fraction of cells are the most difficult to treat, this is the fraction of cells that we want to target with chemotherapies, including KDAC inhibitors. The difference in cellular REDOX environment between physoxic (4-7.5\% oxygen) and hypoxic $(<2.0 \% \text { oxygen })^{27}$ cells provides the opportunity to develop pro-drugs that selectively release their cargo in hypoxia. ${ }^{28}$ This 
strategy has been employed by us and others with some success. ${ }^{28}$ We have previously reported an hypoxia-activated kinase inhibitor, ${ }^{29}$ strategies and protocols for developing and evaluating hypoxia-activated pro-drugs, ${ }^{19}$ a new mechanism for imaging of hypoxia, ${ }^{30}$ and an hypoxia-activated pro-drug of isopropyl 1-thio- $\beta-D$-galactopyranoside (IPTG), allowing us to place gene expression under the control of hypoxia. ${ }^{31}$ Here we report initial work towards the development of KDAC inhibitors that are selectively released in hypoxic conditions (Figure 1B). 


\section{RESULTS AND DISCUSSION}

Hypoxia-activated pro-drugs require addition of a bioreductive group to a functionality that is necessary for the compound to be active, producing a compound that is inactive until deprotected. To be released effectively, the functional group needs a relatively low $\mathrm{p} K_{\mathrm{a}}$, so that the fragmentation step, which happens following bioreduction, occurs in a facile manner. Based on these criteria, we selected the hydroxamic acid as a good position to attach the bioreductive group. Others have used this position as a suitable point of attachment when developing pro-drugs of SAHA (vide supra). Based on the above considerations, compounds NB-SAHA (2, Figure 1B) and NI-SAHA (3, Figure 2) were designed, in which the hydroxamic acid is protected with the 4-nitrobenzyl or 1-methyl-2nitroimidazole group, respectively.

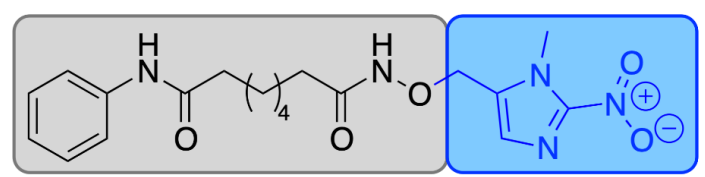

NI-SAHA (3, pro-drug) inactive against KDACs

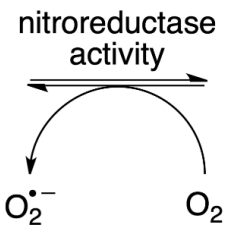

rapid back oxidation occurs under normoxia<smiles>CCCC(=O)NOCc1cnc([N+](=O)[O-])n1C</smiles>

further reduction

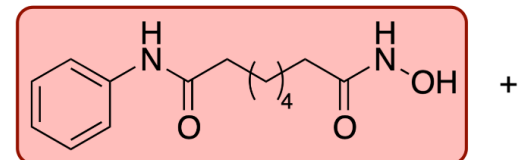

SAHA (1)

active KDAC inhibitor

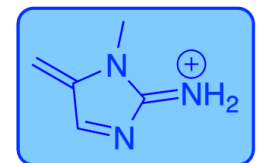

fragmentation

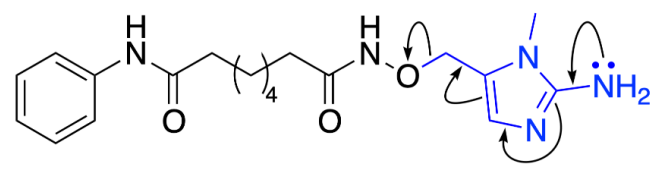

Figure 2. Attachment of the 1-methyl-2-nitroimidazole group to SAHA (1) gives the pro-drug NISAHA (3), which does not inhibit KDAC1-9 or 11. Under hypoxic conditions the nitro group is reduced to form an electron-donating substituent. This reduction results in fragmentation and release of the active KDAC inhibitor SAHA (1).

The synthesis of suberanilic acid (6) and SAHA (1) followed the route reported by Mai et al. (Scheme 1). ${ }^{32}$ Briefly, suberic acid was heated with acetic anhydride to give suberoyl anhydride (5), which was then treated with aniline to give suberanilic acid (6). Reaction of 6 with ethyl chloroformate, to form the presumed mixed anhydride, followed by addition of hydroxylamine gave the hydroxamic acid SAHA (1). 
<smiles>CC(CC(=O)O)CC(=O)O</smiles>

4

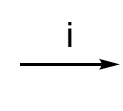

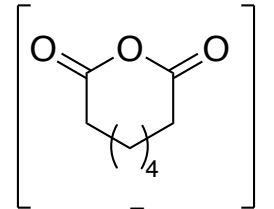

5

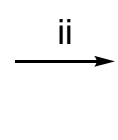

$\mathrm{Ph}$<smiles>O=C(O)CCCCCC(=O)Nc1ccccc1</smiles>

6

iii<smiles>CC(CC(=O)NO)CC(=O)Nc1ccccc1</smiles>

1

Scheme 1. The synthesis of suberanilic acid (6) and SAHA (1). Reagents and conditions: (i) $\mathrm{Ac}_{2} \mathrm{O}$, $140{ }^{\circ} \mathrm{C}$; (ii) $\mathrm{PhNH}_{2}, \mathrm{THF}, \mathrm{rt}, 27 \%$ over two steps; (iii) (a) Ethyl chloroformate, $\mathrm{Et}_{3} \mathrm{~N}$, THF, rt; (b) Hydroxylamine hydrochloride, $\mathrm{KOH}, \mathrm{MeOH}$, rt, $66 \%$ over two steps.

NB-SAHA (2) was synthesised as shown in Scheme 2. N-Hydroxyphthalimide (7) was alkylated with 4-nitrobenzyl chloride to give 8 . The phthalimide group was removed by treatment with concentrated $\mathrm{HCl}$ to give the benzylhydroxylamine 9 . Coupling of 9 and suberanilic acid (6) using EDCl gave NBSAHA (2).<smiles>O=C1c2ccccc2C(=O)N1O</smiles>

7

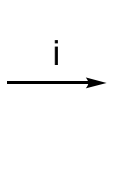<smiles>CN1C(=O)c2ccccc2C1=O</smiles>

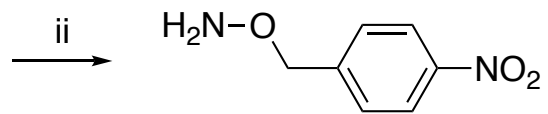

9

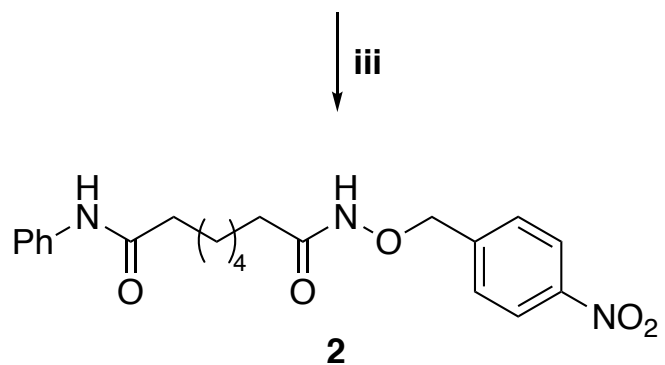

Scheme 2. The synthesis of NB-SAHA (2). Reagents and conditions: (i) DIPEA, 4-nitrobenzyl chloride, DMF, $70{ }^{\circ} \mathrm{C}, 84 \%$; (ii) $\mathrm{HCl}\left(18 \mathrm{M}\right.$, aq.), $\mathrm{EtOH}, 80{ }^{\circ} \mathrm{C}, 90 \%$; (iii) $\mathrm{EDCl} \cdot \mathrm{HCl}, \mathrm{HOBt}, \mathrm{Et}_{3} \mathrm{~N}, 6$ then 9, THF: $\mathrm{CH}_{2} \mathrm{Cl}_{2}(1: 1)$, rt, $8 \%$.

NI-SAHA (3) was obtained by alkylation of SAHA (1) with 5-(chloromethyl)-1-methyl-2-nitro-1Himidazole (10), which was synthesised in a manner similar to that previously reported (Scheme S1). ${ }^{18,19}$ 
<smiles>CC(CC(=O)Nc1ccccc1)CC(C)(C)CC(=O)NNc1ccccc1</smiles>

Scheme 2. The synthesis of NI-SAHA (3). Reagents and conditions: (i) $\mathrm{NaOH}_{\mathrm{aq}}(10 \mathrm{M}), \mathrm{MeOH}, \mathrm{rt}$, $19 \%$.

As we have protected the polar hydroxamic acid group, the solubility of NB-SAHA (2) and NI-SAHA (3) were determined using a Turbidimetric Aqueous Solubility assay (Cyprotex, see SI for raw data). These data show that NB-SAHA (2) is estimated to be soluble at a concentration of at least $10 \mu \mathrm{M}$, and that NI-SAHA (3) is estimated to be soluble at a concentration of at least $100 \mu \mathrm{M}$. As would be expected, these values are slightly lower than the reported solubility of SAHA (1) (soluble at concentrations of at least $724 \mu \mathrm{M}){ }^{33}$

NB-SAHA (2) and NI-SAHA (3) were then evaluated in an KDAC inhibition assay (Reaction Biology, see SI for raw data) against KDAC1-9 and KDAC11 (Table 1). While SAHA (1) shows effective inhibition of these enzymes, neither NB-SAHA (2) nor NI-SAHA (3) showed any detectable inhibition at concentrations up to $10 \mu \mathrm{M}$. These data are consistent with other reports of pro-drug strategies in which the hydroxamic acid of SAHA has been protected (vide supra).

Table 1. $I C_{50}$ values (nM) for SAHA (1), NB-SAHA (2) and NI-SAHA (3) against KDAC1-9 and KDAC11. The colour scale represents a heat map, with 'hot' colours showing high enzyme inhibition.

\begin{tabular}{c|cccccccccc}
\hline \multirow{2}{*}{ Compound } & \multicolumn{10}{c}{ IC $_{50}(\mathbf{n M})^{a}$} \\
\cline { 2 - 11 } & KDAC 1 & KDAC 2 & KDAC 3 & KDAC 4 & KDAC 5 & KDAC 6 & KDAC 7 & KDAC 8 & KDAC 9 & KDAC11 \\
\hline SAHA $^{b}$ & 61.8 & 241 & 257 & 154 & 101 & 20 & 2488 & 212 & 182 & 100 \\
(Vorinostat, 1) & \pm 10.4 & \pm 17 & \pm 83 & \pm 33 & \pm 40 & \pm 3.24 & \pm 881 & \pm 20 & \pm 46.8 & \pm 39.5 \\
\hline NB-SAHA (2) & $\mathrm{NI}$ & $\mathrm{NI}$ & $\mathrm{NI}$ & $\mathrm{NI}$ & $\mathrm{NI}$ & $\mathrm{NI}$ & $\mathrm{NI}$ & $\mathrm{NI}$ & $\mathrm{NI}$ & $\mathrm{NI}$ \\
\hline NI-SAHA (3) & $\mathrm{NI}$ & $\mathrm{NI}$ & $\mathrm{NI}$ & $\mathrm{NI}$ & $\mathrm{NI}$ & $\mathrm{NI}$ & $\mathrm{NI}$ & $\mathrm{NI}$ & $\mathrm{NI}$ & $\mathrm{NI}$ \\
\hline
\end{tabular}

${ }^{a}$ Data obtained by Reaction Biology, $\mathrm{NI}=$ no inhibition observed at concentrations up to $10 \mu \mathrm{M}$. ${ }^{b}$ Data taken from Arts et al. ${ }^{34}$

To determine whether NB-SAHA (2) and NI-SAHA (3) undergo reduction and fragmentation to give SAHA (1), NB-SAHA (2) and NI-SAHA (3) were reduced using zinc and ammonium chloride, and the products analysed using LCMS. ${ }^{38}$ For NI-SAHA (3), reduction to the amine was observed within 15 min and, in addition, fragmentation to SAHA (1) was observed (Figure S1). After this time, the reduction of NI-SAHA (3) plateaued, but the formation of SAHA (1) increased steadily (Figure S1). NB-SAHA (2) showed no fragmentation to SAHA (1) in DMF, however, both the corresponding nitroso and amine derivatives were observed within $15 \mathrm{~min}$ (data not shown). Aliquots of reduced NB-SAHA (2) and NI-SAHA (3) at $\mathrm{t}=16 \mathrm{~h}$ were incubated in phosphate buffer for $24 \mathrm{~h}$ at $37^{\circ} \mathrm{C}$. While 
no discernible increase in SAHA (1) was observed for the reduced NI-SAHA (3) sample, the reduced NB-SAHA (2) sample showed a substantial increase in SAHA (1). These data indicate that both NBSAHA (2) and NI-SAHA (3) undergo reduction upon treatment with zinc and ammonium chloride. However, NI-SAHA (3) can undergo immediate fragmentation to SAHA (1), while NB-SAHA (2) requires the addition of aqueous phosphate buffer to promote fragmentation and production of SAHA (1).

We next evaluated the bioreduction and fragmentation of these compounds to determine whether SAHA (1) would be selectively released in hypoxic conditions. To achieve this, we used bactosomal human NADPH-CYP reductase (CYP004, Cypex) at concentrations of either $9.2 \mathrm{pmol} / \mathrm{mL}$ (Figure 3) or $92 \mathrm{pmol} / \mathrm{mL}$ (Figure S2). A concentration of $9.2 \mathrm{pmol} / \mathrm{mL}$ enzyme correlates most accurately with the degree of hypoxia activation seen in cells. ${ }^{31}$ However, in previous work, ${ }^{19,31}$ we have not always seen significant bioreduction and fragmentation of the nitrobenzyl group at the lower enzyme concentration. Therefore, to determine whether NB-SAHA would release SAHA at all we used both concentrations. When $9.2 \mathrm{pmol} / \mathrm{mL}$ enzyme was used, NI-SAHA (3) was completely stable at $21 \%$ oxygen and no release of SAHA (1) was detected (Figure $3 A$ ). At $<0.1 \%$ oxygen 3 underwent bioreduction and showed significant release of SAHA (1) (Figure 3A). Under the same conditions, NB-SAHA (2) was stable at $21 \%$ oxygen, but showed only a modest release of SAHA (1) at $<0.1 \%$ oxygen (Figure 3B). At the higher enzyme concentration both compounds showed appreciable bioreduction at both $21 \%$ and $<0.1 \%$ oxygen. Analysis of the enzymatic reduction of NI-SAHA (3), using LCMS, showed the presence of the expected mass for SAHA (1, Figure S3).

These data indicate that NI-SAHA (3), at least, will be capable of undergoing bioreduction and fragmentation to release SAHA (1) in cells. ${ }^{19,29}$ They indicate that the use of bioreductive groups to mask the hydroxamic acid moiety of KDAC inhibitors is a viable approach to developing compounds that selectively released in hypoxic tumours. While SAHA (1) is an excellent model compound on which to conduct these studies, it has a half-life of approximately 0.5 hours in human plasma, ${ }^{14}$ and 1.5-2.0 hours when given orally to patients with advanced cancer. ${ }^{15}$ Future work will focus on using more metabolically stable KDAC inhibitors, for example panobinostat, which has a half-life of approximately 30 hours when given orally to patients with advanced solid tumours. ${ }^{35}$ 
A NI-SAHA (3) enzymatic reduction

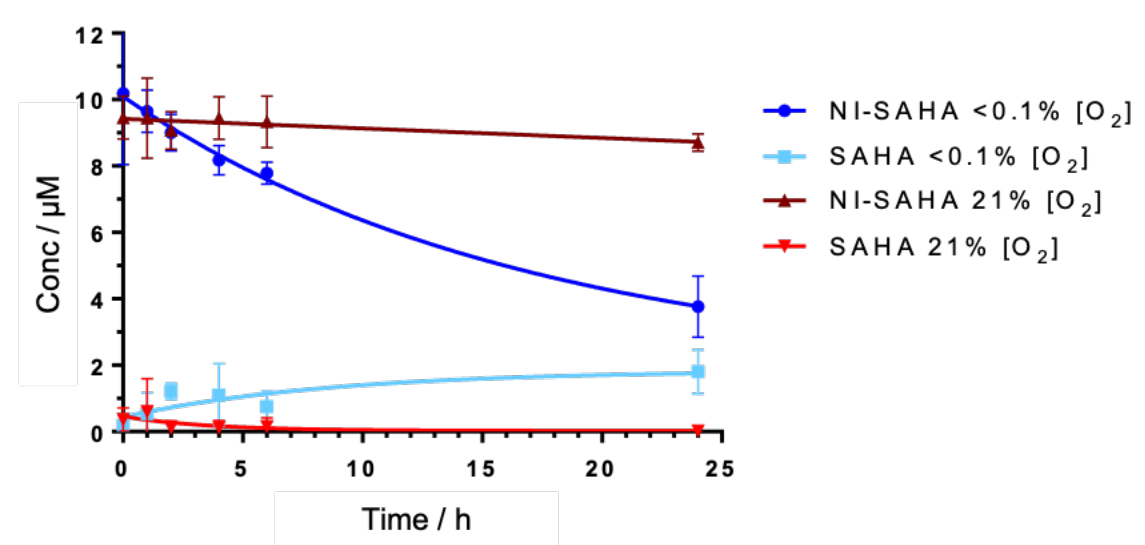

B NB-SAHA (2) enzymatic reduction

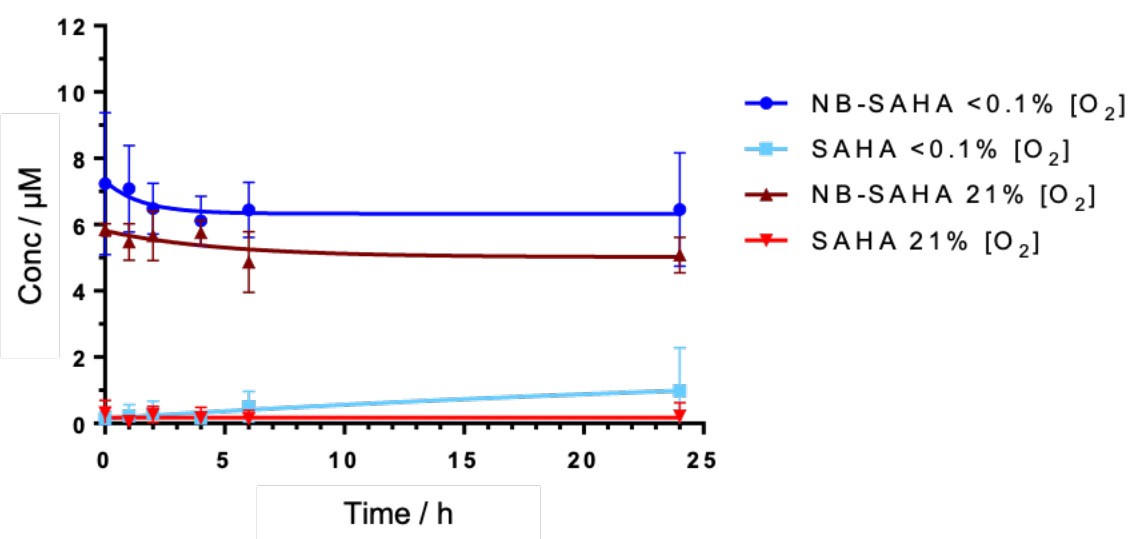

Figure 3. The enzymatic $(9.2 \mathrm{pmol} / \mathrm{mL}$ Bactosomal human NADPH-CYP reductase [CYP004, Cypex]) reduction of NI-SAHA (3) and NB-SAHA (2) at $21 \%$ oxygen (red lines) and $<0.1 \%$ oxygen (blue lines). A. NI-SAHA (3) was completely stable at $21 \%$ oxygen and no release of SAHA was detected (red lines). At $<0.1 \%$ oxygen 3 underwent bioreduction and showed significant release of SAHA (1). B. NB-SAHA (2) was stable at $21 \%$ oxygen, but showed only a modest release of SAHA (1) at $<0.1 \%$ oxygen.

\section{CONCLUSION}

In conclusion, we have shown that the addition of a 4-nitrobenzyl or 1-methyl-2-nitroimidazole bioreductive group onto the hydroxamic acid moiety of SAHA (1) abolishes KDAC inhibition activity, giving NB-SAHA (2) and NI-SAHA (3). NI-SAHA (3) underwent efficient enzyme-mediated bioreduction in a hypoxia-dependent manner, releasing SAHA (1) selectively in $<0.1 \%$ oxygen. This work provides an important foundation for further investigations into the targeted release of KDAC inhibitors in hypoxic tumours. Future work will focus on the development of pro-drugs using more metabolically-stable parent KDAC inhibitors, with the aim of yielding pro-drugs that are more suitable for use in vivo. 


\section{EXPERIMENTAL SECTION}

General Chemistry Procedures

Chemicals were purchased from Acros Organics, Alfa Aesar, Apollo Scientific, Fisher Scientific, Fluka, Fluorochem, Merck or Sigma Aldrich and were used without further purification. Brine refers to a saturated, aqueous solution of sodium chloride. Hexane refers to a mixture of hexane isomers. Petroleum ether refers to the fraction boiling between $40-60^{\circ} \mathrm{C}$, unless otherwise stated. Molecular sieves were activated in an oven at $400{ }^{\circ} \mathrm{C}$. Celite ${ }^{\circledR}$ refers to Celite ${ }^{\circledR} 545$ filter aid, treated with sodium carbonate, flux-calcined, which was purchased from Sigma Aldrich. Where appropriate and if not otherwise stated, all non-aqueous reactions were carried out under an inert atmosphere of argon, using flame-dried glassware.

Anhydrous solvents were obtained under the following conditions: THF, acetonitrile, dichloromethane, diethyl ether and DMF were dried by passing them through a column of active basic alumina according to Grubbs' procedure and stored over activated $3 \AA$ molecular sieves under argon. ${ }^{36}$ Anhydrous methanol and ethanol was purchased from Sigma Aldrich UK in SureSeal ${ }^{\mathrm{TM}}$ bottles and used without further purification.

Analytical thin layer chromatography (TLC) was performed on normal phase Merck silica gel 60 F254 aluminium-supported thin layer chromatography sheets. Spots were visualised by either absorption under UV light ( $254 \mathrm{~nm}$ ), exposure to iodine vapour or thermal development after dipping into a solution of ammonium molybdate in sulfuric acid, an aqueous solution of potassium permanganate or an ethanolic solution of ninhydrin. Reaction progress was monitored at appropriate times by TLC.

Normal phase silica gel flash column chromatography was performed manually using Geduran Silicagel $60(40-63 \mu \mathrm{m})$ under a positive pressure of compressed nitrogen. In vacuo refers to the removal of solvents under reduced pressure using a Büchi ${ }^{\mathrm{TM}}$ rotary evaporator in a water bath at $40^{\circ} \mathrm{C}$, unless otherwise specified. Vacuum transfer refers to the removal of solvents on a manifold linked to a high vacuum pump at rt.

${ }^{1} \mathrm{H}$ NMR spectra were recorded on a Bruker AVIIIHD $400(400 \mathrm{MHz})$ a Bruker AVII 500 with dual ${ }^{13} \mathrm{C}\left({ }^{1} \mathrm{H}\right)$ cryoprobe $(500 \mathrm{MHz})$ or a Bruker AVIIIHD $500(500 \mathrm{MHz})$ spectrometer with the stated solvents as a reference for the internal deuterium lock. Chemical shifts are reported as $\delta \mathrm{H}$ in parts per million $(\mathrm{ppm})$ relative to tetramethylsilane $(\mathrm{TMS})$ where $\delta \mathrm{H}(\mathrm{TMS})=0.00 \mathrm{ppm}$. The spectra are calibrated using the solvent peak with the data provided by Fulmer et al. ${ }^{37}$ The multiplicity of each signal is indicated by: $s$ (singlet), br s (broad singlet), d (doublet), dd (doublet of doublets), ddd (doublet of doublet of doublets), $t$ (triplet), q (quartet), sept (septet), or m (multiplet). The number of protons $(n)$ for a given resonance signal is indicated by $\mathrm{nH}$. The shift values of resonances are quoted to 2 decimal places unless peaks have similar chemical shifts, in which case 3 decimal places are used. Where appropriate, coupling constants $(J)$ are quoted in $\mathrm{Hz}$. Identical proton coupling constants are averaged in each spectrum and reported to the nearest $0.1 \mathrm{~Hz}$. The coupling constants were determined by analysis using Bruker TopSpin software (versions 3.2 and 4.0) or Mestrenova 
software (version 11). ${ }^{1} \mathrm{H}$ spectra were assigned using 2D NMR experiments including COSY, HSQC and ${ }^{13} \mathrm{C}-{ }^{1} \mathrm{H}$ HMBC.

${ }^{13} \mathrm{C}$ NMR spectra were recorded on a Bruker AVIIIHD $400(101 \mathrm{MHz})$ or a Bruker AVII 500 with dual ${ }^{13} \mathrm{C}\left({ }^{1} \mathrm{H}\right)$ cryoprobe $(126 \mathrm{MHz})$ spectrometer in the stated solvents with broadband proton decoupling and an internal deuterium lock. Chemical shifts are reported as $\delta C$ in parts per million (ppm) relative to tetramethylsilane $(T M S)$ where $\delta C(T M S)=0.00 \mathrm{ppm}$. The spectra are calibrated using the solvent peak with the data provided by Fulmer et al. ${ }^{37}$ The shift values of resonances are quoted to 1 decimal place unless peaks have similar chemical shifts, in which case 2 decimal places are used. ${ }^{13} \mathrm{C}$ spectra were assigned using 2D NMR experiments including HSQC and ${ }^{13} \mathrm{C}-{ }^{1} \mathrm{H} H M B C$.

Electrospray ionisation (ESI) mass spectra were acquired using an Agilent 6120 Quadrupole spectrometer or Waters LCT Premier spectrometer, operating in positive or negative mode, as indicated, from solutions of $\mathrm{MeOH}$ or $\mathrm{MeCN}$. Chemical ionisation $(\mathrm{Cl})$ mass spectra were acquired using a Waters GCT spectrometer. MS data was processed using MestReNova software (version 11). $\mathrm{m} / \mathrm{z}$ values are reported in Daltons and followed by their percentage abundance in parentheses. Accurate mass spectra were obtained using Bruker $\mu$ TOF spectrometer. $\mathrm{m} / \mathrm{z}$ values are reported in Daltons. When a compound was not observed by LRMS, only HRMS is quoted.

Melting points were determined using a Kofler hot stage and are uncorrected. The solvent of crystallisation is shown in parentheses.

Infrared (IR) spectra were obtained either from neat samples, either as liquids or solids, or as a thin film using a diamond ATR module. The spectra were recorded on a Bruker Tensor 27 spectrometer. Absorption maxima are reported in wavenumbers $\left(\mathrm{cm}^{-1}\right)$. Only the main, relevant peaks have been assigned.

Compound purity was determined by analytical high-performance liquid chromatography (HPLC) on a PerkinElmer Flexar system with a Binary LC Pump and UV/Vis LC Detector. All biologically tested compounds were of $>95 \%$ purity by HPLC. For determination of compound purity on reversed phase (RP) a Dionex Acclaim $^{\circledR} 120$ column $(C 18,5 \mu \mathrm{m}, 12 \AA, 4.6 \times 150 \mathrm{~mm})$ was employed with water as eluent $A$ and acetonitrile as eluent $B$. Samples were injected in methanol, water or acetonitrile. For each compound, one of two methods were used as described below:

Method A refers to no modifier added.

Method $B$ refers to the addition of $0.1 \% v / v$ TFA.

\begin{tabular}{|c|c|c|c|c|}
\hline Time $(\min )$ & Flow $(\mathrm{mL} / \mathrm{min})$ & $\% \mathrm{~A}$ & $\% \mathrm{~B}$ & Slope \\
\hline 5 & 1.5 & $95 \%$ & $5 \%$ & 0 \\
\hline 10 & 1.5 & $5 \%$ & $95 \%$ & 1 \\
\hline 5 & 1.5 & $5 \%$ & $95 \%$ & 0 \\
\hline
\end{tabular}




\section{Semi-preparative HPLC details}

HPLC purification of NI-SAHA (3) was carried out on Waters Autopurification system, "equipped with a Waters X-Bridge OBD semi-prep column (19 mm x $50 \mathrm{~mm}, 5 \mu \mathrm{m})$, with an injection loop of $1 \mathrm{~mL}$, eluting with $\mathrm{H}_{2} \mathrm{O}+0.1 \%$ Formic acid/MeOH $+0.1 \%$ formic acid. The crude samples (in $\mathrm{MeOH}$ ) were filtered (nylon, $0.2 \mu \mathrm{m}$ ) and injected in $750 \mu \mathrm{L}$ aliquots, with mass-directed purification with an ACQUITY QDa performance mass spectrometer.

*Full details: Waters 2767 Sample manager; Waters 2998 Photodiode array detector; Waters ACQUITY QDa; Waters SFO (systems fluidics organiser) and Waters 2545 Binary Gradient Module.

Method:

$\mathrm{A}=\mathrm{H}_{2} \mathrm{O}+0.1 \%$ formic acid

$\mathrm{B}=\mathrm{MeOH}+0.1 \%$ formic acid

\begin{tabular}{|c|c|c|c|c|}
\hline Time $(\min )$ & Flow $(\mathrm{mL} / \mathrm{min})$ & $\% \mathrm{~A}$ & $\% \mathrm{~B}$ & Slope \\
\hline 0 & 25 & 95 & 5 & 0 \\
\hline 1 & 25 & 95 & 5 & 0 \\
\hline 17 & 25 & 5 & 95 & 1 \\
\hline 18 & 25 & 5 & 95 & 0 \\
\hline 20 & 25 & 95 & 5 & 1 \\
\hline
\end{tabular}

Experimental details and characterisation for suberanilic acid (6), ${ }^{31} \quad \mathrm{~N}$-hydroxy- $N^{\prime}-$ phenyloctanediamide (SAHA, 1) $)^{37}, \quad N$-phthalimido-O-(4'-nitrobenzyl)-hydroxylamine $(\mathbf{8})^{38}, \quad$ O-(4nitrobenzyl)-hydroxylamine (9) ${ }^{38}$, ethyl (2-amino-1-methyl-imidazol-5-yl)carboxylate (S3) ${ }^{17-19}$, ethyl

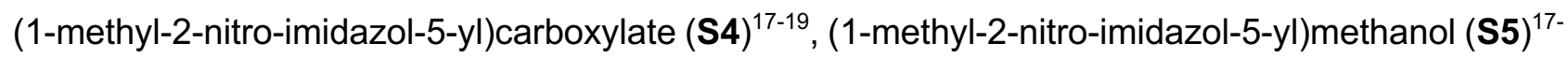
${ }^{19}$ and (1-methyl-2-nitro-imidazol-5-yl)methyl chloride (10 ${ }^{17-19}$ can be found in the supplementary information. 


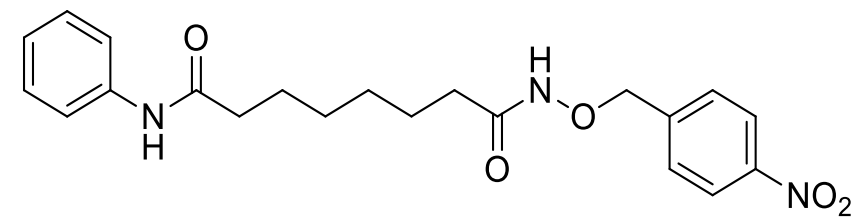

Suberanilic acid $(6,0.20 \mathrm{~g}, 0.80 \mathrm{mmol}, 1.0 \mathrm{eq})$ was dissolved in a mixture of tetrahydrofuran $(10 \mathrm{~mL})$ and dichloromethane $(10 \mathrm{~mL})$. Triethylamine $(0.56 \mathrm{~mL}, 4.0 \mathrm{mmol}, 5.0 \mathrm{eq})$ was added to the solution followed by 1-ethyl-3-(3-dimethylaminopropyl)carbodiimide hydrochloride (0.23 g, $1.2 \mathrm{mmol}, 1.5 \mathrm{eq}$ ) and the reaction was stirred for $0.75 \mathrm{~h}$ at rt. O-(4-Nitrobenzyl)-hydroxylamine $(9,0.27 \mathrm{~g}, 1.6 \mathrm{mmol}$, $2.0 \mathrm{eq}$ ) was added and the reaction was stirred at $\mathrm{rt}$ for a further $18 \mathrm{~h}$. The reaction was quenched with hydrochloric acid $(1 \mathrm{M}, 20 \mathrm{~mL})$ and extracted with dichloromethane $(20 \mathrm{~mL})$. The organic components were washed with hydrochloric acid $(1 \mathrm{M}, 20 \mathrm{~mL})$, water $(20 \mathrm{~mL})$, and brine $(20 \mathrm{~mL})$, dried $\left(\mathrm{Na}_{2} \mathrm{SO}_{4}\right)$, filtered, and concentrated in vacuo. Purification by column chromatography (ethyl acetate: petroleum ether 30-40, 20-100\%) to yield compound 2 ( $25 \mathrm{mg}, 8 \%$ ) as a colourless solid. $R_{f} 0.52$ (ethyl acetate); $\mathrm{mp} 150-152{ }^{\circ} \mathrm{C}$ (from EtOAC); $v_{\max }$ (thin film)/ $\mathrm{cm}^{-1} 3233,2981,2885,1658$, 1602, 1524, 1382, 1346, 1253, 1153, 1072; ${ }^{1} \mathrm{H}$ NMR (500 MHz, DMSO-D $) \delta_{H} 11.06(1 \mathrm{H}, \mathrm{s}), 9.83$ $(1 \mathrm{H}, \mathrm{s}), 8.24(2 \mathrm{H}, \mathrm{d}, J$ 8.4), $7.67(2 \mathrm{H}, \mathrm{d}, J$ 8.4), $7.57(2 \mathrm{H}, \mathrm{d}, J$ 7.9), $7.27(2 \mathrm{H}, \mathrm{dd}, J$ 7.9, 7.6), $7.01(1 \mathrm{H}$, $\mathrm{t}, J 7.6), 4.93(2 \mathrm{H}, \mathrm{s}), 2.27(2 \mathrm{H}, \mathrm{t}, J 7.4), 1.94(2 \mathrm{H}, \mathrm{t}, J 7.3), 1.55(2 \mathrm{H}, \mathrm{tt}, J 7.4,7.4), 1.48(2 \mathrm{H}, \mathrm{tt}, J$ 7.4, 7.3), 1.31-1.18 (4H, m); ${ }^{13} \mathrm{C}$ NMR (126 MHz, DMSO-D 6 ) $\delta_{\mathrm{C}} 180.7,179.1,156.7,153.6,148.8$, 138.8, 138.1, 132.9, 132.4, 128.5, 85.0, 45.8, 41.6, 37.8, 37.7, 34.4, 34.2; HRMS m/z (ESI ${ }^{+}$) Found: 400.18600, $\mathrm{C}_{21} \mathrm{H}_{26} \mathrm{~N}_{3} \mathrm{O}_{5}$ requires [M+H] ${ }^{+}$400.18670; LRMS m/z $\left.\left(\mathrm{ESI}^{+}\right) 422(100 \% \text {, [M+Na] }]^{+}\right) ; \mathrm{HPLC}$ Method A, Retention time $-8.4 \mathrm{~min}, 95 \%$.

\section{N-((1'-Methyl-2'-nitroimidazol-5'-yl)methoxy)-N'-phenyloctanediamide (3)}<smiles>Cn1c(CONC(=O)CCCCCCC(=O)Nc2ccccc2)cnc1[N+](=O)[O-]</smiles>

$N$-Hydroxy- $N$ '-phenyloctanediamide $(1,20 \mathrm{mg}, 0.076 \mathrm{mmol}, 1.0 \mathrm{eq})$ was dissolved in a mixture of methanol $(0.8 \mathrm{~mL})$ and aqueous, $10 \mathrm{M}$ sodium hydroxide $(0.016 \mathrm{~mL}, 0.16 \mathrm{mmol}, 2.1 \mathrm{eq})$. (1-Methyl2-nitro-imidazol-5-yl)methyl chloride $(10,20 \mathrm{mg}, 0.11 \mathrm{mmol}, 1.5 \mathrm{eq})$ was added, the reaction was stirred at it for $11 \mathrm{~h}$ then concentrated in vacuo. The residue was dissolved in chloroform and filtered then concentrated in vacuo. The residue was triturated first with chloroform and then with ethyl acetate before the residue was dissolved in a minimal amount of methanol and purified by semipreparative HPLC, using general conditions (product elution at $10.5 \mathrm{mins}$ ). Solvent was removed with a stream of nitrogen, over $18 \mathrm{~h}$ at $\mathrm{rt}$, then dried by vacuum transfer to yield compound 3 as a colourless solid (7.5 mg, 19\%). $R_{f} 0.28$ (5\% ethanol in chloroform); mp 137-139 ${ }^{\circ} \mathrm{C}$ (from water); $V_{\max }\left(\right.$ thin film) $/ \mathrm{cm}^{-1} 3200,2934,2860,1663,1559,1544,1495,1443,1333,1278,1189 ;{ }^{1} \mathrm{H}$ NMR $\left(500 \mathrm{MHz}, \mathrm{DMSO}_{-} \mathrm{D}_{6}\right) \delta_{\mathrm{H}} 11.05(1 \mathrm{H}, \mathrm{s}), 9.84(1 \mathrm{H}, \mathrm{s}), 7.57(2 \mathrm{H}, \mathrm{d}, J$ 8.0), $7.27(2 \mathrm{H}, \mathrm{dd}, J$ 8.0, 7.6), 
$7.25(1 \mathrm{H}, \mathrm{s}), 7.01(1 \mathrm{H}, \mathrm{t}, J 7.6), 4.89(2 \mathrm{H}, \mathrm{s}), 4.03(2 \mathrm{H}, \mathrm{s}), 2.28(2 \mathrm{H}, \mathrm{t}, J 7.4), 1.94(2 \mathrm{H}, \mathrm{t}, J 7.3), 1.57$ $(2 \mathrm{H}, \mathrm{tt}, J 7.4,7.3), 1.47(2 \mathrm{H}, \mathrm{tt}, J 7.3,7.3), 1.32-1.20(4 \mathrm{H}, \mathrm{m}) ;{ }^{13} \mathrm{C}$ NMR $\left(126 \mathrm{MHz}, \mathrm{DMSO}-\mathrm{D}_{6}\right) \delta_{\mathrm{c}}$ 171.2, 169.8, 139.3, 132.8, 129.5, 128.6, 122.9, 119.0, 65.4, 36.3, 34.4, 32.1, 28.4, 28.3, 25.0, 24.7; HRMS m/z $\left(\mathrm{ESI}^{+}\right)$Found: $404.19382, \mathrm{C}_{19} \mathrm{H}_{26} \mathrm{~N}_{5} \mathrm{O}_{5}$ requires [M+H] $]^{+}$404.19285; LRMS $\left(\mathrm{ESI}^{+}\right) 830$ $\left([2 \mathrm{M}+\mathrm{Na}]^{+}, 100 \%\right), 808\left([2 \mathrm{M}+\mathrm{H}]^{+}, 35 \%\right), 608(21 \%), 426\left([\mathrm{M}+\mathrm{Na}]^{+}, 64 \%\right), 404\left([\mathrm{M}+\mathrm{H}]^{+}, 23 \%\right), 258$ (13\%), 102 (24\%); HPLC Method B, Retention time - $7.0 \mathrm{~min},>99 \%$.

\section{Zinc reduction assay}

The chemical reduction was carried out as previously described. ${ }^{19}$ Briefly, the compound of interest, NB-SAHA or NI-SAHA $(2.5 \mu \mathrm{mol})$, was combined in DMF $(2 \mathrm{~mL})$ with aqueous ammonium chloride $(20 \mu \mathrm{L}, 10 \% w / v)$. A sample $(100 \mu \mathrm{L})$ of this was removed $(\mathrm{t}=0 \mathrm{~h})$ before zinc powder $(5 \mathrm{mg}$, $0.077 \mathrm{mmol}$ ) was added. At predetermined timepoints ( $\mathrm{t}=0.25,0.5,1,4,16,24 \mathrm{~h})$, a sample $(100 \mu \mathrm{L})$ was removed and filtered through a nylon syringe filter $(0.2 \mu \mathrm{M}, 4 \mathrm{~mm})$. Analysis by LCMS determined the percentage reduction. To determine the percentage fragmentation, a sample of the reaction mixture $(5 \mu \mathrm{L})$ at selected timepoints were collected and combined with $\mathrm{K}_{2} \mathrm{HPO}_{4}$ buffer $(95 \mu \mathrm{L}, 0.1 \mathrm{M}, \mathrm{pH} 7.4)$ and incubated at $37^{\circ} \mathrm{C}$ for $24 \mathrm{~h}$. LCMS analysis was carried out on a Waters 2695 separations module. Separation was achieved on an ACE C18, $3 \mu \mathrm{m}, 150 \times 3 \mathrm{~mm}$ column (Hichrom, UK) maintained at $40{ }^{\circ} \mathrm{C}$. Samples were eluted in A: $0.1 \%$ formic acid, B. Acetonitrile containing $0.1 \%$ formic acid with a flow rate of $0.4 \mathrm{~mL} / \mathrm{min}$, and a linear gradient of $40-90 \% \mathrm{~B}$ in 6 $\mathrm{min}$, total run time $10 \mathrm{~min}$. Analytes were measured using a mass spectrometer with a Waters Acquity QDa detector with electrospray ionisation in a positive ionisation mode $(0.8 \mathrm{kV})$, source temperature $600^{\circ} \mathrm{C}$. 


\section{Enzyme reduction assay}

Bactosomal human NADPH-CYP reductase (9.2 or $92 \mathrm{pmol} / \mathrm{mL}$, CYP004, Cypex) was used in combination with NADPH-regenerating system (Cat. No 451220 and Cat No 451200, Corning) as described previously. ${ }^{19} \mathrm{NI}$-SAHA and NB-SAHA were prepared as $10 \mathrm{mM}$ stock solutions in DMSO, and their final concentration in the reaction mixture was $10 \mu \mathrm{M}$. Enzymatic reactions were carried out under normoxic $\left(21 \% \mathrm{O}_{2}\right)$ or hypoxic $\left(<0.1 \% \mathrm{O}_{2}\right)$ conditions. Samples $(50 \mu \mathrm{L})$ were taken at regular intervals, quenched with $50 \mu \mathrm{L} \mathrm{MeCN} / \mathrm{MeOH}$ (1:1) and analysed by HPLC or LCMS. HPLC analysis was carried out on a Waters 2695 separations module with a Waters 2996 photodiode array detector. Separation was achieved on a RPB C18 reversed phase column, $5 \mu \mathrm{m}, 100 \times 3.2$ column (Hichrom, UK) maintained at $35^{\circ} \mathrm{C}$. Samples were eluted in A: $0.1 \%$ formic acid, B: acetonitrile with a flow rate of $0.5 \mathrm{ml} / \mathrm{min}$, and a linear gradient of $20-100 \% \mathrm{~B}$ in $6 \mathrm{~min}$, total run time $10 \mathrm{~min}$. Analytes were detected at $254 \mathrm{~nm}$; NI-SAHA had a retention time of $4.8 \mathrm{~min}$, NB-SAHA had a retention time of $5.6 \mathrm{~min}$ and SAHA had a retention time of $3.8 \mathrm{~min}$.

LCMS analysis was carried out on a Waters 2695 separations module. Separation was achieved on an ACE C18, $3 \mu \mathrm{m}, 150 \times 3 \mathrm{~mm}$ column (Hichrom, UK) maintained at $40{ }^{\circ} \mathrm{C}$. Samples were eluted in $\mathrm{A}: 0.1 \%$ formic acid, $\mathrm{B}$. Acetonitrile containing $0.1 \%$ formic acid with a flow rate of $0.4 \mathrm{~mL} / \mathrm{min}$, and a linear gradient of $40-90 \%$ B in $6 \mathrm{~min}$, total run time $10 \mathrm{~min}$. Analytes were measured using a mass spectrometer with a Waters Acquity QDa detector with electrospray ionisation in a positive ionisation mode $(0.8 \mathrm{kV})$, source temperature $600^{\circ} \mathrm{C}$. NI-SAHA was detected with a cone voltage of $13 \mathrm{~V}$ at selected ion recording (SIR) of $\mathrm{m} / \mathrm{z} 404.2(\mathrm{M}+\mathrm{H})$, retention time $3.7 \mathrm{~min}$, NB-SAHA with a cone voltage of $13 \mathrm{~V}$ and SIR of $\mathrm{m} / \mathrm{z} 400.2(\mathrm{M}+\mathrm{H})$, retention time $5.5 \mathrm{~min}$ and SAHA with a cone voltage of $11 \mathrm{~V}$ and SIR of $\mathrm{m} / \mathrm{z} 265.15(\mathrm{M}+\mathrm{H})$, retention time $2.5 \mathrm{~min}$. In addition, analytes were monitored in the same system using absorbance spectroscopy with a Waters 2996 photodiode array detector.

\section{ACKNOWLEDGEMENTS}

E.D.D.C., I.N.M., A.S., S.J.C., and E.M.H. thank the Medical Research Council for funding (MR/N009460/1). S.J.C., D.S. and E.M.H thank the Engineering and Physical Sciences Research Council for Programme Grant support (EP/S019901/1). E.M.H. received research funding from Cancer Research UK. S.J.C. thanks St Hugh's College, Oxford, for research support. The authors thank Dr Nicola Farrer for use of her HPLC equipment. 


\section{REFERENCES}

(1) Allfrey, V.; Faulkner, R.; Mirsky, A. Proc. Natl. Acad. Sci. USA 1964, 51, 786.

(2) Kouzarides, T. EMBO J 2000, 19, 1176.

(3) Choudhary, C.; Weinert, B. T.; Nishida, Y.; Verdin, E.; Mann, M. Nat. Rev. Mol. Cell Biol. 2014, 15, 536.

(4) Choudhary, C.; Kumar, C.; Gnad, F.; Nielsen, M. L.; Rehman, M.; Walther, T. C.; Olsen, J. V.; Mann, M. Science 2009, 325, 834.

(5) Turner, B. M. Nat. Cell Biol. 2007, 9, 2.

(6) Schiedel, M.; Conway, S. J. Curr. Opin. Chem. Biol. 2018, 45, 166.

(7) Hewings, D. S.; Rooney, T. P. C.; Jennings, L. E.; Hay, D. A.; Schofield, C. J.; Brennan, P. E.; Knapp, S.; Conway, S. J. J. Med. Chem. 2012, 55, 9393.

(8) Conway, S. J. ACS Med. Chem. Lett. 2012, 3, 691.

(9) Brand, M.; Measures, A. M.; Wilson, B. G.; Cortopassi, W. A.; Alexander, R.; Höss, M.; Hewings, D. S.; Rooney, T. P. C.; Paton, R. S.; Conway, S. J. ACS Chem. Biol. 2015, 10 , 22.

(10) Schiedel, M.; Moroglu, M.; Ascough, D. M. H.; Chamberlain, A. E. R.; Kamps, J. J. A. G.; Sekirnik, A. R.; Conway, S. J. Angew. Chem. Int. Ed. 2019, 58, 17930.

(11) Cochran, A. G.; Conery, A. R.; Sims, R. J. Nat. Rev. Drug Discov. 2019, 18, 609.

(12) Gryder, B. E.; Sodji, Q. H.; Oyelere, A. K. Future Med. Chem. 2012, 4, 505.

(13) Daniel, K. B.; Sullivan, E. D.; Chen, Y.; Chan, J. C.; Jennings, P. A.; Fierke, C. A.; Cohen, S. M. J. Med. Chem. 2015, 58, 4812.

(14) Konsoula, R.; Jung, M. Int. J. Pharm. 2008, 361, 19.

(15) Kelly, W. K.; O'Connor, O. A.; Krug, L. M.; Chiao, J. H.; Heaney, M.; Curley, T.; MacGregore-Cortelli, B.; Tong, W.; Secrist, J. P.; Schwartz, L.; Richardson, S.; Chu, E.; Olgac, S.; Marks, P. A.; Scher, H.; Richon, V. M. J. Clin. Oncol. 2005, 23, 3923.

(16) Rubin, E. H.; Agrawal, N. G. B.; Friedman, E. J.; Scott, P.; Mazina, K. E.; Sun, L.; Du, L.; Ricker, J. L.; Frankel, S. R.; Gottesdiener, K. M.; Wagner, J. A.; Iwamoto, M. Clin. Cancer Res. 2006, 12, 7039.

(17) Parveen, I.; Naughton, D. P.; Whish, W.; Threadgill, M. D. Bioorg. Med. Chem. Lett. 1999, 9, 2031.

(18) O'Connor, L. J.; Cazares-Körner, C.; Saha, J.; Evans, C. N. G.; Stratford, M. R. L.; Hammond, E. M.; Conway, S. J. Org. Chem. Front. 2015, 2, 1026.

(19) O'Connor, L. J.; Cazares-Korner, C.; Saha, J.; Evans, C. N. G.; Stratford, M. R. L.; Hammond, E. M.; Conway, S. J. Nature Protocols 2016, 11, 781.

(20) Schlimme, S.; Hauser, A.-T.; Carafa, V.; Heinke, R.; Kannan, S.; Stolfa, D. A.; Cellamare, S.; Carotti, A.; Altucci, L.; Jung, M.; Sippl, W. ChemMedChem 2011, 6, 1193.

(21) Liu, S.; Zhang, K.; Zhu, Q.; Shen, Q.; Zhang, Q.; Yu, J.; Chen, Y.; Lu, W. Bioorg. Med. Chem. 2019, 27, 1405.

(22) Bhagat, S. D.; Singh, U.; Mishra, R. K.; Srivastava, A. ChemMedChem 2018, 13, 2073.

(23) Liao, Y.; Xu, L.; Ou, S.; Edwards, H.; Luedtke, D.; Ge, Y.; Qin, Z. ACS Med. Chem. Lett. 2018, 9, 635.

(24) Rubio-Ruiz, B.; Weiss, J. T.; Unciti-Broceta, A. J. Med. Chem. 2016, 59 (21), 9974.

(25) Höckel, M.; Vaupel, P. J. Natl. Cancer Inst. 2001, 93, 266.

(26) Brown, J. M.; Wilson, W. R. Nat. Rev. Cancer 2004, 4, 437.

(27) McKeown, S. R. Br. J. Radiol. 2014, 87, 20130676.

(28) Mistry, I. N.; Thomas, M.; Calder, E. D. D.; Conway, S. J.; Hammond, E. M. Int. J. Radiat. Oncol. Biol. Phys. 2017, 98, 1183.

(29) Cazares-Korner, C.; Pires, I. M.; Swallow, I. D.; Grayer, S. C.; O'Connor, L. J.; Olcina, M. M.; Christlieb, M.; Conway, S. J.; Hammond, E. M. ACS Chem. Biol. 2013, 8, 1451.

(30) O'Connor, L. J.; Mistry, I. N.; Collins, S. L.; Folkes, L. K.; Brown, G.; Conway, S. J.; Hammond, E. M. ACS Central Science 2017, 3, 20.

(31) Collins, S. L.; Saha, J.; Bouchez, L. C.; Hammond, E. M.; Conway, S. J. ACS Chem. Biol. 2018, 13, 3354.

(32) Mai, A.; Esposito, M.; Sbardella, G.; Massa, S. Org Prep Proced Int 2001, 33 (4), 391.

(33) Cai, Y. Y.; Yap, C. W.; Wang, Z.; Ho, P. C.; Chan, S. Y.; Ng, K. Y.; Ge, Z. G.; Lin, H. S. J Clin Pharm Ther 2010, 35, 521. 
(34) Arts, J.; King, P.; Mariën, A.; Floren, W.; Beliën, A.; Janssen, L.; Pilatte, I.; Roux, B.; Decrane, L.; Gilissen, R.; Hickson, I.; Vreys, V.; Cox, E.; Bol, K.; Talloen, W.; Goris, I.; Andries, L.; Jardin, Du, M.; Janicot, M.; Page, M.; van Emelen, K.; Angibaud, P. Clin. Cancer Res. 2009, 15, 6841.

(35) Sharma, S.; Witteveen, P. O.; Lolkema, M. P.; Hess, D.; Gelderblom, H.; Hussain, S. A.; Porro, M. G.; Waldron, E.; Valera, S.-Z.; Mu, S. Cancer Chemother Pharmacol 2015, 75, 87.

(36) Pangborn, AB; Giardello, M. A.; Grubbs, R. H.; Rosen, R. K.; Timmers, F. J. Organometallics 1996, 15, 1518.

(37) Fulmer, G. R.; Miller, A. J. M.; Sherden, N. H.; Gottlieb, H. E.; Nudelman, A.; Stoltz, B. M.; Bercaw, J. E.; Goldberg, K. I. Organometallics 2010, 29, 2176. 